\title{
Independent Research and a Deep Approach to Learning of Accounting Concepts: Students' View
}

\author{
Fortune Ganda \\ University of Limpopo, Turfloop Graduate School of Leadership (TGSL) \\ P.O. Box 756, Fauna Park, Polokwane 0787, South Africa \\ Corresponding author: Email: Fochi555@yahoo.com \\ Collins C Ngwakwe \\ University of Limpopo, Turfloop Graduate School of Leadership (TGSL) \\ P.O. Box 756, Fauna Park, Polokwane 0787, South Africa \\ Email: collins.ngwakwe@ul.ac.za

\section{M Ambe} \\ University of Limpopo, School of Accountancy, \\ P/Bag X1106, Sovenga, 0727, South Africa \\ Email: cosmas.ambe@ul.ac.za
}

\section{Doi:10.5901/mjss.2014.v5n6p75}

\begin{abstract}
This article examines students' views on the role of independent research on students' Deep Approach to learning of accounting concepts. The article thus draws from a questionnaire administered to final year Bachelor of Accounting Science (Chartered Accountant stream) and Bachelor of Commerce Accounting (Commerce stream) students at the University of Limpopo, South Africa. Outcomes produced from the Chi-square analysis on students' responses demonstrates that, from their point of view, independent research on accounting concepts does support the deep learning of accounting concepts. Moreover, a positive association involving independent learning and improved understanding of accounting concepts was also successfully realised. In addition, most of the students indicated that teaching staff should encourage them to engage independent research which stimulates them to deeply comprehend taught subject matter extensively. Nonetheless, more research is important to examine if actual students' understanding of accounting concepts was improved through employing independent research as the learning method. As well, it is essential to investigate the long-run professional advancement implication about how independent study supports Deep Approach to learning. It is also vital to support the view that studying accounting is not just an issue of rote learning specific collections of standards. Thus, present educational practices in accounting education must create environments that promote independent research that enhances students to adopt Deep Approaches to learning more than Surface Approaches. The students' perspectives indicated the significance of engaging independent research in their learning process, which is important towards developing Deep Approaches to learning.
\end{abstract}

Keywords: Independent learning; Deep Approach to learning; Accounting concepts

\section{Introduction}

Contemporary teaching and learning techniques appear to revolve more around classroom oriented teaching and thus more teacher centred. But experts have criticized Teacher Centred approach in learning as inimical to students' lifelong academic development and growth. For instance, reports from various accounting associations and agencies have criticised the way by which accounting teaching staff have continued to adopt traditional lecture-oriented methods, use of textbook based tasks, and setting examinations that only require memorisation of facts (The Big Eight, 1989; and AICPA,1996). Therefore, there has been an increasing call to integrate autonomous real-life skills in accounting education (Burnet, 2003) that enhance problem-solving and critical-thinking skills (Needles \& Powers, 1990).

Necessarily, in response to the growing effort by the South African government to improve teaching and learning (Council of Higher Education, 2009), this paper measures students' perceptions of independent research on Deep Approach to learning of accounting concepts. In the same vein, SAICA (2010) has considered new standards and skills in 
which inexperienced entry-level accounting professionals are expected to adhere to in its competency framework. Hence, globalisation and quick transformation, with respect to information and communication appliances, has put increased pressure on present day accounting graduates (International Federation of Accountants, 2003) to make use of essential personal, soft and life expertise instead of technical ones (Howieson, 2003). Ubiquitously, we experience with dismay the frequency of what is termed student consultation; indeed we feel dismayed to behold students consult on trivial matters that demand self-research and/or study - to find out, evaluate and thus internalise facts that previously seemed nebulous to learners.

Thus, the problem that motivates this study draws from both prior criticism of Teacher-Centred learning, and from the researchers' personal experience with students' overdependence on lecturers for learning activities; which thus seem to be affecting their level of personal critical reasoning and independent learning ability. Accordingly, the paper seeks to answer the question - does students' independent research or study of accounting concepts enhance Deep Approaches to learning of accounting concepts. The objective of this article is thus to investigate if independent research or study does enhance students' deep understanding of accounting concepts.

This paper is important considering the importance of education toward social and economic development, and the current South African national government stance in declaring education as an essential service if desired development must be achieved (Bauer, 2013). Thus, it assists policy makers in the primary, secondary and tertiary educational systems of developing countries to develop appropriate curriculums that enhance independent study. Moreover, teaching staff will be given the opportunity to utilise teaching methods that foster a sense of authoritative reasoning, independent thought and self-confidence on part of the students. Piaget, as quoted in Flavell (1963), expresses that people are frequently motivated to learn when their own cognitive structures have not been able to solve existing challenges. This implies that the teaching staff must give students tasks that cause the learners to move from learning contexts they already understand. So, the accounting profession is able to achieve greater success once accounting education has embraced independent learning techniques (Martin \& Wilkerson, 2006) instead of promoting passive learning.

The article is organised as follows: the next section discusses the linkage between independent research and students' learning ability. This is followed by a discussion of the Deep Approach to learning theory, succeeded by a section that highlights how independent research or study enhances deep learning. Following this is research method, data analysis and research implications for accounting educators. The final section presents drawn conclusions.

\subsection{Independent Research and Students' Learning}

Independent research and/or learning is a teaching and learning approach that enables a student to have a certain degree of autonomy from the teacher in thinking and researching concepts so as to enhance self-understanding (Holec,1981). Thus, it empowers students to take control of their academic activities, stimulate them to address personal learning needs, broaden the scope of study outside the classroom and reduce dependence on academic staff and peers (Lamb, 2004). In light of this view, independent learning is an instrument that develops human mental capacity to be very critical and highly inquisitive (Najoua et al. 2005). By motivating students to thirst for knowledge, self-research demands an individual to understand where, when and how to study, so that the students can be motivated, comprehend new concepts and exercise their academic skills (Essential Study Skills, 2013). It has also been associated with the ability to cause students to be able to manage everyday life problems (Boer, 2000).

Essentially, Marton (1981) informs that students need to apply learned concepts so as to independently interpret their facts. Unlike many years ago when students were identified as a passive information storage structure; the learner is actually a self-determining agent who chooses information from own environmental settings, and formulates new ideas in accordance to his/her prior knowledge (Shuell, 1986). On that account, the content about learning is developed and expressed in agreement with the student's personalised motive, along with available conceptual systems (Driver \& Easley, 1978). Thus, students are fully engaged to reflect on their learning process (Candy 1991; and Percy \& Salter, 1976). Moreover, the learning process is characterised by absence of social interaction, for example lectures and tutorials (Moore, 1973).

Fundamentally, the prime educational objective in accounting education is to attain high quality learning outcomes. As such, these include the student's better technical abilities, wide knowhow about the field, critical thinking skills and the ability to integrate problem solving techniques (Accounting Education Change Commission, 1992) - ideally characteristic features of self-study (Accounting Education Change Commission, 1990). Therefore, these components of independent learning move the student from being a "product of his society" to be a "producer of his society" (Holec, 1981). As such, doing away with procedural assignments and recalling accounting professional standards, by adopting a well-defined and analytical individualised learning process, is important (Davidson, 2002) since students are engaged in the process of 
making their own mental frameworks (Newman et al.,2003).

In light of this view, learners are given the room and freedom to develop responsibility and accountability towards their educational work, which makes the student "workplace ready" (Choy et al., 2008). Consequently, self-study propels students to self-pace their learning process, exercise their best thinking and improve individual time management (Anderson et al., 2007). Thus, the teaching staff in accounting must support case study tasks, along with distinctive work assignments so as to reinforce individualised student communication and skill acquisition (Rebele et al., 1998). Such a practice is effective since students look for the required information on their own (Dziewulski \& Childs, 2012), which also removes the burden on teaching staff when they find it difficult to apply instructor-centred approaches (Arkoudis \& Love, 2008).

Essentially, a study on an Australian university demonstrates that supporting independent study in accounting produces more effective teaching and learning outcomes (Luke \& Hogarth, 2011). Indeed, the advantages associated with independent study have been connected with widening the scope of the students' capability to learn, and giving them a model that they can use to examine challenges (AGDEET, 1987), reason critically, plus acquire deeper comprehension on learned material (Percy \& Salter, 1976).

Necessarily, studies completed in a UK university prove that the advent of computerised technology has enormously supported the global adoption of self-research learning approaches (Dewhurst et al., 2000). As a result, the use of technology represents one of the fundamental methods by which independent learning can be enhanced (Rubena, 2003). For example, Blayney and Freeman (2004) utilised Excel-generated evaluations that are given to learners so that drill-and-practice accounting education activity is promoted, along with analysing and summarising student learning development at a specific point in time. That being so, the approach is not the same for every learner: hence it eliminates superficial methods, along with shortcuts, which include obtaining the solution from a colleague. As well, to evaluate correct solutions, learners make use of cell-referenced formulas that foster comprehension about fundamental subject matter. In a related study, Lehman and Herring (2003) utilised Microsoft Excel features in giving accounting questions to learners and, besides fostering independent learning, the technique also possess important functions such as "hint" and "comment" sections that further widen students' individualised knowledge.

It is also an open view that there has been many and advanced financial reporting principles that introduce problems to accounting teaching staff and learners (Samkin \& Francis, 2008). Hence, the growing expectations on teaching staff, along with supervising big classes, has caused more problems (Strickland, 1985), which are also increased by differences among learners (Biggs, 1999) since they have different knowledge competencies (Lucas \& Mladenovic, 2009) and different skills (Zapalska \& Dabb, 2002). These diversities make it difficult for students to learn in a single class environment (Luke \& Hogarth, 2011). So, independent learning creates a better academic setting that reduces differences and complexities involved in growing educational systems (As-Saber et al., 2006) by making use of instruments that promote self-paced, along with self-directed learning (Race, 2005).

\subsection{Deep Approach to Learning Theory}

The Deep Approach to learning is constituted with individualised engagement towards a learning process, adequate prior knowledge and high curiosity concerning the subject matter. On the one hand, it fosters learners to become selfresearchers, realise accountability towards their learning process and develop individualised abstract structures concerning acquired information (Entwistle, 1988). On the other hand, it is also propelled if the teacher demonstrates individual interest on the concept, links new knowledge to basic foundation contexts learners have acquired, commits students in an active learning process through showing compatibility and impartiality when appraising expected learning performances (Biggs, 1999; and Entwistle, 1988). On that account, the teacher is incapable of delivering Deep Approach to learning but can generate environments in which that can develop (Grayling, 2011).

Necessarily, Marton and Säljo (1976) initially demonstrated important differences on students' capacity to understand using the terms deep and surface levels of processing. In subsequent years, Marton and Säljo (1976) renamed the aspects and identified them as deep and Surface Approaches to learning by highlighting that the method cannot be a "process" but instead, constituted by "intention" factor. On that account, the technique was a function of activities performed by students through reliance on context, together with content of that study (Entwistle, 1991). This eventually produced a consistent pattern through which the learners adopted the same approach to learning on a much wider scope. However, the learners' perception concerning the learning setting is able to determine how the learner acquires knowledge and not the context of the study (Entwistle, 1987; and Biggs, 1989). For example, learners who depend on Surface Approach to learning highly favour teachers who provide them with knowledge that is already prepared for learning purposes, whilst learners who rely on Deep Approach to learning like teachers who give them a 
challenging environment, together with the subject matter that motivates them (Entwistle \& Tait,1990). Fundamentally, important differences involving deep and Surface Approaches to learning that have been identified by Entwistle and Entwistle (1991) are summarised in Table 1 below:

Table 1: Important differences involving deep and Surface Approaches to learning

\begin{tabular}{|l|l|}
\hline \multicolumn{1}{|c|}{ Deep Approaches to Learning } & \multicolumn{1}{c|}{ Surface Approaches to Learning } \\
\hline Seek to understand concepts for self-benefit & Relates to actions that reproduce learning material \\
\hline $\begin{array}{l}\text { Involves robust and decisive intercommunication of } \\
\text { content material }\end{array}$ & Concepts are understood passively \\
\hline Establish connection with prior knowledge & $\begin{array}{l}\text { Specialise on knowledge material that is crucial for evaluation } \\
\text { purposes }\end{array}$ \\
\hline Discover and incorporates ideas & $\begin{array}{l}\text { Absence pertaining to reflection about the motive or ways in the } \\
\text { learning process }\end{array}$ \\
\hline Compare evidence against final outcomes & Routine acceptance of facts and processes \\
\hline Assess the logic behind every dispute & Inability to differentiate leading standards or trends \\
\hline Probable results: Deep Approach & Probable results: Surface Approach \\
\hline Improved ability to recognise and transfer knowledge & No involvement with subject matter \\
\hline $\begin{array}{l}\text { Quality results are better comprehension of subject matter } \\
\text { and critical thinking ability }\end{array}$ & $\begin{array}{l}\text { Minimised chances of encountering high-quality learning results } \\
\text { or generate suitable ability and proficiency. }\end{array}$ \\
\hline
\end{tabular}

Source: Entwistle, N.J., and Entwistle, A.C. (1991)

As in the table above, it can be ascertained that Deep Approach to learning is focused on developing interest on concepts associated with assigned work which optimise understanding on such matter thereby satisfying the existing curiosity (Biggs, 1989). On the other hand, Surface Approach is a function of extrinsic motivation, so the student tends to limit their learning goals towards necessary matters, which can be generated again by rote learning (Biggs, 1989). For instance, vital outcomes point out that an accounting learner undertakes superficial methods towards the learning process that is constituted with rote acquisition of knowledge and this affects generation of quality learning results (Bauer et al. 1994). Moreover, it conforms with Beattie et al.'s (1997) view that the accounting discipline draws a considerable number of students who employ Surface Approaches to learning. It follows that when learners are directed in ways that surpass surface learning, owing to better chances that increase their performance in the learning procedure, then they eventually secure favourable standards involving curiosity, comprehension and stimulation (Laird et al., 2008).

Therefore, Deep Approaches to learning concentrates on primary definitions; specialises on key aspects and objectives; plus learners participate purposely as well as suitably. In this manner, students are optimistic, become gripped and feel challenged, hence academic questions they are given cause them to develop an investigative mentality (Harrison, 2004). In the end, deep learning is afforded when learners find interrelationships with their course contexts, recognise the significance of learned aspects, as well as use these aspects in their everyday life scenarios (DeLotell et al., 2010).

\subsection{How Independent Research Enhance Deep Approaches to Learning}

Accounting learners in universities are expected to produce distinct learning results (QAAHE, 2000). So, it is crucial to inculcate a culture that involves self-research in students, capable of propelling them to deeper and appreciable levels of academic mastery (Gill \& Halim, 2007). Marriot (2002) postulates that students are able to acquire Deep Approaches to learning techniques once they have been given adequate reasons and opportunities. Hence, it is possible to put off Surface Approaches that support rote methods of learning through designing learning environments and evaluations that enhance individualised problem solving and critical assessments (Ramsden, 1992). In another study, the International Federation of Accountants (IFAC) informs that "if accounting graduates are to meet the future challenges of the profession, they must develop the knowledge, skills and competencies necessary to become independent, lifelong learners" (Byrne, Flood \& Willis, 2004, p. 451).

Eley (1992) studied that accounting learners at Monash University show larger levels and lower levels of surface and Deep Approaches to learning when they were compared to science and arts students, respectively. In line with this view, Lucas (2001) suggests that students take on Surface Approaches since they fear handling figures and numbers involved in accounting. As such, Sharma (1997) indicates that enhancing Deep Approaches to learning among students 
is very crucial in order to produce competent qualified accountants. So, independent learning is about being inventive, employing dynamism, determining outcomes, as well as being experimental. All these essentials propel a student as an individual to attain a deeper understanding on learned subject matter since it develops interest in them, plus they become motivated and are driven by passion to recognise ultimate outcomes (Palfreyman \& Baba, 2010).

Ideally, independent learning affords a learner an opportunity to generate a research culture that equips them with essential individual and professional expertise. It as well promotes inquiry-oriented learning and support structured learning processes, which eventually develop deep methods of understanding (Russel International Excellence Group, 2010). Referring to a study involving MATLAB course at the University of Sheffield, students were not advancing academically because they could not employ Deep Approaches of learning. Hence, a scheme involving programming that supports independent learning was instituted so that learners acquire personal confidence (Rossiter, 2010). Moreover, they adopt individual study techniques that enhance them to gain knowledge and competence, as well as commit those learning aspects to problem solving situations.

Thus, problem-solving based challenges make students to be more aligned with independent learning (Candy, 1991) since they prioritise their spare time for more study and challenge their knowledge status (Boud, 1988). Such characteristics build accountability and a sense of responsibility towards their learning course, which in turn enhances them to follow the Deep Approach to learning applications (Smith \& Turner, 2012). Thus, various aspects concerning Deep Approaches to learning are achievable through improved student self-study as the classroom knowledge material cannot completely cover every concept to be learnt. The investigative and inquiry sense a learner develops, initiates their level of mental cognitive status to further expand. In the same vein, Deppe et al., (1991) demonstrate that abstract reasoning ability, inquiry competencies, individual communication and leadership skills are among the most relevant proficiencies required in the accounting profession.

As it stands, students' structured instruction emanates from employing a diversified range of Deep Approach to learning techniques as a result of increased cognitive growth (Pascarella et al. 2012). But, evidence suggests that accounting teaching staff utilise teaching techniques that do not promote Deep Approaches to learning (Cherry \& Reckers, 1985). For example, teaching staff fail to make use of important learning methods such as case studies (Libby, 1991). Doran et al. (2011, p. 245) point out that, as regards accounting education, "case studies can be successfully delivered in large class settings." Fundamentally, the use of case studies affords students an opportunity to assume learning processes on their own, thereby creating independence, which further leads them to adopt Deep Approaches to learning since they are confronted with conceptual subject matter that challenges them. This removes the classroom setting by establishing personal learning environments that also assists students to focus on a wider scope of their academic activity (Read \& Hurford, 2008) which enhance self-belief and critical analysis skills through ways that link accounting subject matter with the social world (Chabrak \& Craig, 2013).

Intuition in the student is also an important part of Deep Approach to the learning process that can be developed through self-research. Rorty (1967, p.205) expresses intuition as "immediate apprehension" and Arnheim (1962, p.9) demonstrates intuition as "the underlying vision of what is to be attained." Laevers (1998) argues that intuition is an act of knowing without utilising rational processes; therefore, it is a deeper stage of cognition, capable of making progressive effect on learning processes as learners conceive reality situations and express them. Therefore, the teaching staff can foster intuition by making use of specific goals and objectives in clearly defined curriculum guides and lesson plans (Waks, 2006). Peters (1964) described intuition practised in education as "initiation into worthwhile activities" since it brings educational value. Evidently, the academic staff must not just deliver knowledge to the learner without making considerable impact on students' intuition, as their subsequent lesson delivery successes depend on those intuitions.

Intuitions go hand in hand with reflections (White, 2008). Reflections support a learner to develop independent thoughts (Little, 1991) that foster Deep Approaches to learning. This has been made possible since most academic institutions expect students to give account of what they have learned through various educational forums. Hence, the process involved with Deep Approach to learning is fostered through reflective processes of "learning by doing" (Kolb, 1976). For that reason, learners are compelled to pay attention to their thoughts, as well as enunciate verbally or in writing every outcome of those long considerations (Hinett, 2002). So, Samkin and Francis (2008) proposed a learning portfolio that encourages the simultaneous adoption of various ways that support Deep Approaches to learning by creating personalised strong analytical and constructive judgement competencies among students studying towards an accounting degree.

Given that, Baeten et al. (2010) interpret that the students must also be content with applicability of assigned tasks, methods of teaching and evaluation attached, along with explicitness of goals so as to attain deeper understanding of learned subject matter. Therefore, students must take individualised steps and action since learning is a function of both the learner and the environment (Trigwell \& Prosser, 1991). Gow et al. (1994) inform that Deep Approaches to learning 
among accounting undergraduate students are practised highly in the first year, but Gordon and Debus (2002) noted that students in all subjects usually adopt Deep Approaches to learning as they progress from first year to third year and more in the fifth year (Cope \& Staehr, 2005). It follows then that the inability of accounting students to deeply reflect on their learning process and make use of acquired skills to solve problems, significantly affects the learner to exercise independent study (Francis et al.,1995). That being so, better accounting education practices are achievable through fully addressing the importance of Deep Approaches to learning (Booth et al.,1999).

Adler et al. (2000) suggest that accounting teachers do not put much serious thought as regards to their teaching methods, and they do not institute measures on how learners can individually improve their level of understanding. So, they speculate that teachers need to put much focus on procedures by which independent learning takes place. On that account, on-going construction and improvement of these learning procedures, along with devising new methods which support the learning environment shall demand teachers to for-go their own personal ideas about the learning process (Donald \& Jackling, 2007). Briefly, Lucas (2000, p. 502) founds out that "the teaching of accounting should seek to acknowledge, and enter into, the students' own worlds of accounting." Necessarily, such a change is possible as results from a study conducted on first-year accounting students found out that the learners showed a steady increase towards adopting Deep Approaches to learning as the semester progresses (Hall et al., 2004). The following section presents the research method and analysis.

\section{Research Method}

\subsection{Sample}

This article is based on a case study of final year accountancy students at the University of Limpopo, South Africa. The study sample is made up of the entire Bachelor of Accounting Science students (Chartered Accountant stream) and the Bachelor of Commerce in Accounting students (Commerce stream). Both accounting streams were sampled so that the pattern on whether students' independent research or study of accounting concepts can enhance deep learning of accounting concepts from their perspective would not show particular aspects about that specific stream more than the whole accounting discipline. That being so, it argument and give a generalised illustration about accounting courses of study in a South African university. Necessarily, the sample included the final year students since they have more experience and have encountered a diverse range of teaching and learning methods practised at tertiary education level than junior students. Biggs (1987) demonstrates that older learners make use of Deep Approach to learning than adopting Surface Approach to learning. The BAccSci students were surveyed when a final year auditing course lecture was being conducted. The BComAcc students were also surveyed when a management accounting course was being conducted. Thus, the instrument initially was issued out to a total of 167 students who were available and 162 students subsequently submitted useful returns. Both of these courses are compulsory constituents of the accounting degree for BAccSci and BComAcc programmes. The precise details about gender, response rate and the final sample are presented in the table below:

Table 2: Sample study statistics

\begin{tabular}{|l|c|c|c|}
\hline \multicolumn{1}{|c|}{ Sample Details } & BAccSci sample & BComAcc sample & Total Sample \\
\hline Number surveyed & 72 & 95 & 167 \\
\hline \multirow{2}{*}{ Instruments returned } & 72 & 95 & 167 \\
& $(100 \%)$ & $(100 \%)$ & $(100 \%)$ \\
\hline \multirow{2}{*}{ Useful returns } & 70 & 92 & 162 \\
& $(97.2 \%)$ & $(96.8 \%)$ & $(97 \%)$ \\
\hline \multirow{2}{*}{ Number of males } & 30 & 36 & 66 \\
& $(42.9 \%)$ & $(39.1 \%)$ & $(40.7 \%)$ \\
\hline \multirow{2}{*}{ Number of females } & 40 & 56 & 96 \\
& $(57.1 \%)$ & $(60.9 \%)$ & $(59.3 \%)$ \\
\hline \multirow{2}{*}{ Spoiled responses } & 2 & 3 & 5 \\
& $(2.8 \%)$ & $(3.2 \%)$ & $(3.0 \%)$ \\
\hline
\end{tabular}

Examining the table above, the study shows a distinctively high useful response rate at $97.2 \%$ and $96.8 \%$, when compared to the spoiled responses which are only $2.8 \%$ and $3.2 \%$ for the BAccSci and BComAcc students respectively. Thus, the study contains large sampling rates; something which, to a greater extent, minimises any systematic biases 
that come as a result of the presence of non-responses. Furthermore, both lectures experienced a high attendance rate and there were few spoiled returns, which indicate a high level of maturity on part of the respondents.

\subsection{The survey instrument}

The major instrument considered in this study was the questionnaire; structured in a way that enhances the student to respond by presenting various feedbacks on the effect of independent research on students' deep learning of accounting concepts. In addition, the instrument used some important ideas from Biggs (1987) Study Process Questionnaire (SPQ), especially on matters that relate to Deep Approach to learning. As such, the guidelines from the SPQ have been highly regarded as reliable, establish validity and show internal consistency for suitable data and research (Beattie et al., 1997). As well, the instrument included a Likert scale framework that required the students to simply put a tick in the most suitable column they desired. Therefore, the total number of questions in the questionnaire was eight (8). The key issues in this tool were, namely:

1. Students' independent learning;

2. Students' Deep Approach to learning;

3. Academic performance of students by employing independent learning; and

4. How independent learning enhance Deep Approach to learning methods.

\subsection{Data Analysis}

The data collected from the administered questionnaire on 162 responses were arranged and analysed using table presentations, and the Chi-squared method was also used to further investigate the data. The outcomes of the study are thus presented using the following tables and Chi-square calculations.

\subsection{Table Presentations}

Combined (Bachelor of Accounting Science Degree + Bachelor of Commerce Accounting) - Final year students' Questionnaire outcomes

Table 3: Presentation of findings from question one, three, five, seven and eight of the questionnaire for both groups

\begin{tabular}{|c|c|c|}
\hline QUESTIONS No. 1;3;5;7 and 8 & YES & NO \\
\hline 1. Do your lecturers encourage you to do independent or personal research/study on accounting concepts? & 152 & 10 \\
\hline $\begin{array}{l}\text { 3. Do you think that independent research on accounting concepts assists you to understand concepts } \\
\text { more than the lecturers' class explanation? }\end{array}$ & 98 & 64 \\
\hline $\begin{array}{l}\text { 5. Do you suggest that lecturers should be giving students the opportunity to do personal research or study } \\
\text { on accounting concepts? }\end{array}$ & 137 & 25 \\
\hline 7. I always remember accounting concepts when I do personal research or study on the concepts. & 135 & 27 \\
\hline $\begin{array}{l}\text { 8. Do you believe that learning and understanding of accounting concepts will improve if lecturers } \\
\text { constantly encourage students' personal study or research? }\end{array}$ & 148 & 14 \\
\hline
\end{tabular}

From the table above, the students' perception in emphasizing the importance of independent research about their learning process is outstanding. The students accepted the view that their educators encourage independent study and they always remember the concepts under such an approach. Thus, it conforms to Shuell's (1986) speculation that learning procedures students undertake are very significant in determining how they have understood than what educators do. It is also consistent with the view that the whole teaching and learning process must engage the teaching staff and students in a continuous adaptation procedure which is action-enquiry related (Elliot, 1991). Inevitably, a course design is developed that personally engages students to exercise independent research.

From this study, most students identified independent research as important in assisting them to understand taught subject matter better. In line with this argument, Marton and Ramsden (1988, p 268-286) explain that "...learning should be seen as a qualitative change in a person's way of seeing, experiencing, understanding, conceptualising something in the real world- rather than as a quantitative change in the amount of knowledge someone possesses." Furthermore, the study also showed that students expect teaching staff to give them the opportunity to do independent research. 
Supporting this argument, Stoner and Milner (2010, p. 136) comment that methods that build appropriate skills, such as critical thinking and problem solving, should be done "across the whole degree experiences." Most students also believe that learning and understanding accounting concepts will improve when the teaching staff encourages independent study. Consistent with this view, considerable advantages by employing active learning methods have been identified (Caprariis et al., 2001) since they assist learners to be individually engaged in the learning process (Anderson et al., 2007), as well as develop their own mental structures (Newman et al., 2003). Hence, a strong and deeper learning process in accounting is accomplished when both students and their teachers' needs have been valued so as to create effective instruction frameworks (Brown \& Atkins, 1988).

Table 4: Presentation of findings from question two of the questionnaire for both groups

\begin{tabular}{|c|c|c|c|c|}
\hline QUESTION No. 2. & Always & Sometimes & Once & None \\
\hline 2. How often do your lecturers give you library or online research assignments? & 18 & 115 & 10 & 19 \\
\hline
\end{tabular}

As from table 4 above, most students hold the view that lecturers give them online research tasks though they are not given the assignments on a more consistent basis. Thus, more web facilitated, along with online study material have improved in the past years (Bigelow 1996) including accounting online education (Mahoney \& Dziuban, 2000). Therefore, from this study, it is evident that teaching staff has also noted the importance of using library or online research assignments, which improves independent research skills of the learner. Thus, students who make use of online learning environments outperform learners who are in traditional classroom environment (Zhang et al., 2004). In addition, the use of computers has become crucial in solving accounting challenges (Elliot, 1997). For instance, accountants are expected to understand sophisticated structures associated with information systems, along with making use of their individual thinking competencies to solve various challenges in new contexts (Bateman,1996).

Table 5: Presentation of findings from question four of the questionnaire for both groups

\begin{tabular}{|c|c|c|c|c|}
\hline QUESTION No.4. & Very deeply & Deeply & Fairly & None \\
\hline $\begin{array}{l}\text { 4. To what extent do you understand accounting concepts when you are given } \\
\text { the opportunity to do personal research or study on such concepts? }\end{array}$ & 16 & 42 & 100 & 4 \\
\hline
\end{tabular}

From Table 5 above, most students suggested that they can understand accounting concepts 'fairly' to 'very deeply' when they have been given the opportunity to do personal research. Hence, individual problem-solving and critical-thinking abilities are important in accounting studies (Albrecht \& Sack, 2000; and Barsky et al., 2003). Moreover, an effective teaching and learning method should promote learners to individually understand accounting principles (Turner et al., 1997), at the same time enhancing analytical and critical thinking competency to deeper levels (Catanach et al., 2000). Thus, critical thinking "requires the students to construct actively their own knowledge or solution" by evaluating concepts making use of existing knowledge (Sanchez et al., 1995, p. 69). This is evidenced in this study since the teaching staff gives the students opportunities to do personal research. Similarly, the AACSB (2007) mentioned individualised research abilities (learning and pedagogy) as one of the crucial components of intellectual contributions, in addition to applied research and basic research standards at higher education level. Indeed, accounting students must be able to review and learn academic concepts independent of the class (Anderson \& Boynton, 1992) so as to address the growing expectations of the accounting profession (Dow \& Feldman, 1997).

Table 6: Presentation of findings from question six of the questionnaire for both groups

\begin{tabular}{|l|c|c|c|c|}
\hline \multicolumn{1}{|c|}{ QUESTION No.6 } & $\begin{array}{c}\text { Very } \\
\text { important }\end{array}$ & Important & $\begin{array}{c}\text { Slightly } \\
\text { important }\end{array}$ & $\begin{array}{c}\text { Not } \\
\text { important }\end{array}$ \\
\hline $\begin{array}{l}\text { 6. In your own view, how important is it that lecturers should give } \\
\text { students personal research assignments? }\end{array}$ & 58 & 81 & 20 & 3 \\
\hline
\end{tabular}

Schmutte (1986) demonstrates that the primary test for any given accounting task is the degree to which involved students are able to be academically empowered. From Table 6 above, most students regard personal research tasks as being important to being very important. Supporting this argument, Verduin and Clark (1991) found that the teaching staff's design of study material should primarily show the mode of learning that learners give first preference to. Such a 
practice assists them to realise and respond to different student challenges, thereby improving the learning process. Furthermore, students' view of understanding accounting studies is very significant so as to get rid of possible redundant and non-value adding learning processes (Burnett et al., 2008). Therefore, "[i]n order to promote more conceptual, deeper forms of learning, educators need to understand how students approach learning" (Ballantine, Duff \& Larres, 2008, p. 190).

\subsection{Chi-squared test}

The statistical package on chi-square was utilised to investigate two specific tests. The first test examined the relationship between Independent research and Deep Learning among BAccSci and BComAcc final year students. The second test investigated the relationship between independent research and improved understanding of accounting concepts among BAccSci and BComAcc final year students.

\subsubsection{First test: Examining the relationship between Independent research and Deep learning among BAccSci and BComAcc final year students.}

Using the Chi-squared method:

$\mathrm{Ho}$ : There is no association between independent research and deep learning.

$\mathrm{H}_{1}$ : There is an association between independent learning and deep learning.

Results: The $X^{2}$-statistic value was determined as 8.817768 . The $X^{2}$-critical value was found out to be 3.843 . The level of significance used was 0.05 . The degree of freedom computed was 1 . Therefore, the decision was that we reject $\mathrm{Ho}$ and accept $\mathrm{H}_{1}$. Thus, there is an association between independent learning and deep learning.

\subsubsection{Second Test: Examining the relationship between independent research and improved understanding of accounting concepts among BAccSci and BComAcc final year students.}

Using the Chi-squared method:

Ho: There is no relationship between independent research and improved understanding of accounting concepts.

$\mathrm{H}_{1}$ : There is a relationship between independent learning and improved understanding of accounting concepts.

Results: The $X^{2}$-statistic value was determined as 51.0694 . The $X^{2}$-critical value was found out to be 3.843 . The level of significance used was 0.05 . The degree of freedom computed was 1 . Therefore, the decision was that we reject $\mathrm{Ho}$ and accept $\mathrm{H}_{1}$. Thus, there is a relationship between independent learning and improved understanding of accounting concepts.

From the two chi-squared tests, an examination of the research indicates particular key findings. The first test and the second test prove the importance of independent research on enhancing Deep Approach to learning methods and improved understanding of accounting concepts respectively. Under these circumstances, the study produced a qualifying analysis that investigates the aspect that students who utilise independent learning approaches promote acquisition of Deep Approach learning techniques. Thus, Deep Approach to learning is a probable outcome when better comprehension of subject matter takes place and the student develops critical analytical abilities (Biggs, 1987) which in this case are facilitated by independent research. Furthermore, the findings prove that there is a relationship between independent learning and improved understanding of accounting concepts. That being so, learners who adopt the Deep Approach to learning are mainly involved with grasping fundamental subject matter that they have been taught (Zhang \& Sternberg,2000). Moreover, the outcomes prove that accounting teaching staff can determine learning techniques adopted by learners through implementing significant changes in the educational environment. Thus, it supports Gow et al., (1994) and Zeegers (2001) who document that a student's methods of learning are capable of changing with time. On that account, a student who makes use of independent research is actually adopting and internalising Deep Approaches to learning that eventually results in improved understanding of accounting concepts. Thus, they tend to adopt Deep Approach to learning when they are self-stimulated, actively participate and when they experience knowledge in clearly defined procedures (Gibbs, 1995) which results in better academic performance.

\section{Implications of the Study}

This research has demonstrated the importance of independent research towards fostering Deep Approaches to learning in accounting education from a student's perspective. Thus, Svensson (1977) found that individual learners who make 
use of Deep Approaches to learning have extended study periods and are more interested in their studies as compared to students who adopt surface study approaches. For this reason, it is essential to evaluate existing educational practices in the accounting curriculum, then introduce improvements that enhance students to utilise independent research. Such a practice will encourage students to develop creative, stimulating, analytical and adaptive competencies that are characteristic features of Deep Approach to learning. The American Accounting Association, in The Bedford Report (1986), reports that a more flexible accounting curriculum that discourages passive and rote learning, but instead focused on the student being active and "learning to learn" approach must be supported. So, Deep Approaches to learning produces successful learning results (Pask, 1988).

Using this study, independent research is positively correlated with Deep Approach to learning. Conversely, it implies that there is negative association between Surface Approach and Deep Approach to learning. Therefore, it is necessary to foster and implement educational practices in accounting education that propel students to show less preference towards adopting Surface Approach to learning in accounting. This argument was encouraged by Biggs (1989) who demonstrates that various approaches of handling given work generate different results: 'surface' produce quantitative increase of the subject matter, whilst 'deep' generates qualitatively well-defined results. Indeed, learning tasks and evaluation activities that give greater accountability to the students assist them to gain complex conceptions on taught subject matter, which leads to a deeper comprehension of relevant content material (Gibbs et al., 1984).

Furthermore, Ramsden (1992) briefs that it is difficult to train learners to utilise Deep Approaches to learning if the educational institution demonstrates that Surface Approaches produce positive outcomes. Evidently, students may simply adopt learning methods that make them acquire high scores, instead of understanding the taught subject matter. Thus, clear objectives and principles in accounting education assist to give the students the necessary direction, thereby enhancing them to be accountable towards their individual learning procedure. Regarding this issue, the accounting educational setting can integrate review boards that are constituted with teaching staff, along with students so that the learners understand what is expected from them, as well as evaluate the course of study.

Further study is essential to investigate whether actual student understanding of accounting subject matter was improved by the use of independent research as a learning technique, for instance whether students grades improved or not. This is important so as to actually evaluate student performance since this study only considered their views. Further research is also important to consider the long-run professional advancement implication involving how independent research enhances Deep Approach to learning of accounting concepts.

\section{Conclusion}

This article examined the students' view on the role of independent research on students' deep learning of accounting concepts. The article draws from a case study of final year accountancy students at the University of Limpopo. A questionnaire was administered to obtain students' responses on their view of the role of independent research on students' deep learning of accounting concepts. Responses were analysed using the Chi-square statistic. The results indicate that, according to students' responses, there is an association between independent learning and deep learning and also, a relationship between independent learning and improved understanding of accounting concepts was realised. Furthermore, the majority of the students interviewed are of the view that lecturers should encourage them to engage in independent research and/or study of concepts, which, according them, assists them to better internalise these concepts. The article thus concludes that, given students' view regarding the importance of independent research, and the growing importance being attached to teaching and learning as an essential service in developing countries, the time has come to intensify students' independent research on accounting concepts. Doing this would foster the moulding of future graduates that will have the potential to steer and manage the complex interactions of the country's social and economic issues.

\section{References}

AACSB. (2007). Eligibility procedures and accreditation standards for business accreditation (January). Tampa, FL: AACSB International.

Accounting Education Change Commission. (1990). "Objectives of Education for Accountants: Position Statement Number One," Issues in Accounting Education, Vol.5 No.2, pp. 307-312.

Accounting Education Change Commission. (1992). The First Course in Accounting, Position Statement No. Two, WA: AECC, Bainbridge.

Adler, R.W., Milne, M.J., \& Stringer, C.P. (2000). "Identifying and overcoming obstacles to learner centred approaches in tertiary accounting education: a field study and survey of accounting educators perceptions", Accounting Education, Vol. 9 No.2, pp. 113- 
134.

AGDEET .(1987). Policy Discussion Paper on Higher Education, Australian Government Printing Service, Canberra.

Albrecht, W.S., \& Sack, R.J. (2000). Accounting education: Charting the course through a perilous future. Sarasota, FL: American Accounting Association.

American Accounting Association, The Bedford Report. (1986). "Future Accounting Education: preparing for the expanded profession", Issues in Accounting Education, Vol 1, pp. 168-195.

American Institute of Certified Public Accountants (AICPA). (1996). Special Committee on

Assurance Services. Composite Profile of Capabilities Needed by Accounting Graduates. New York, NY: AICPA.

Anderson, J.A., \& Boynton, W.C. (1992). "Managing the intermediate accounting overload: An experiment," Journal of Accounting Education, Vol. 10 No.2, 297-307.

Anderson, R., Anderson, R., \& Davis, K.M. (2007). Supporting active learning and example based instruction with classroom technology. SIGCSE'07, Covington, Kentucky, USA: 69-73.

Arkoudis, S., \& Love, K. (2008). "Imagined communities in senior school mathematics: Beyond issues of English language ability", Journal of Asian Pacific Communication, Vol. 18 No.1, pp.71-90.

Arnheim, R. (1962). The Genesis of a Painting: Picasso's Guernica, University of California Press.

As-Saber, S., Crosling, G., \& Rahman, N. (2006). "International Students and Independent Learning: Towards an Eclectic Framework", Monash University, available at: http://www.napsipag.org/pdf/sharif-as-saber-inernational.pdf (accessed 02 February 2013).

Baeten, M., Kyndt, E., Struyven, K., \& Dochy, F. (2010). "Using student-centred learning environments to stimulate Deep Approaches to learning: Factors encouraging or discouraging their effectiveness", Educational Research Review, Vol.5, pp. 243-260.

Ballantine, J., Duff, A., \& Larres, P. (2008). "Accounting and business students' approaches to learning: a longitudinal study", Journal of Accounting Education, Vol. 26 No. 4, pp. 188-201.

Barsky, N.P., Catanach, A., \& Kozlwski, B.M. (2003). "Creating Strategic Responses to Critical Risks Facing Accounting Education, Issues In Accounting Education, Vol. 18 No.4, 445 - 462.

Bateman, D.H. (1996). Sharing knowledge. CA Magazine (January/February), 35-8.

Bauer, N. (2013). "ANC moves to make education an essential service", Mail \& Guardian, available at: http://mg.co.za/article/2013-0204-anc-moves-to-make-education-an-essential -service (accessed 09 September 2013)

Bauer, L., Locke, J., \& O'Grady W. (1994). "Introducing accounting education change: a case of first-year accounting", Working Paper, Department of Accounting, Massey University.

Beattie, V., Collins, B., \& Mclnnes, B. (1997). "Deep and surface learning: a simple or simplistic dichotomy?" Accounting Education: an International Journal, Vol. 6 No.1, pp. 1-12.

Bigelow, J. D. (1996). "Developing an Internet section of a management course: Transporting learning premises across media" in Proceedings of the 1996 World Conference in the Web Society, Atlanta, 1996, pp. 13-20.

Biggs, J. (1987). Student Approaches to Learning and Studying, Hawthorn, Australian Council for Educational Research, Victoria.

Biggs, J.B. (1989). "Approaches to the Enhancement of Tertiary Teaching", Higher Education Research \& Development, Vol. 8 No. 1 , pp. 7-25.

Biggs, J.B. (1999). Teaching for Quality Learning at University Buckingham, SRHE and Open University Press.

Blayney, P. J., \& Freeman, M. A. (2004). "Automated formative feedback and summative assessment using individualized spreadsheet assignments", Australasian Journal of Educational Technology, Vol. 20 No.2, pp. 209-231.

Boer, G. B. (2000). "Management accounting education: yesterday, today, and Tomorrow", Issues in Accounting Education, Vol.15 No. 2, pp. 313-334.

Booth, P., Luckett, P., \& Mladenovic, R. (1999). "The quality of learning in accounting education: the impact of approaches to learning on academic performance", Accounting Education: An International Journal, Vol.8 No. 4, pp. 277-300.

Boud, D. (1988), Developing Student Autonomy in Learning, Kogan Press, New York.

Brown, G., \& Atkins, M. (1988). Effective Teaching in Higher Education, Methuen, London.

Burnett, R., Friedman, M., \& Yang, Y. (2008). "The Change of Students' Perception of Accounting Skills in Intermediate Accounting: A Guide for Accounting Education Reform", The Accounting Educators Journal, Volume XVIII, pp. 81 - 101.

Burnett, S. (2003). The future of accounting education: a regional perspective, Journal of Education for Business, January/February, pp. 129-134.

Byrne, M., Flood, B., \& Willis, P. (2004). "Validation of the Approaches and Study Skills Inventory for Students (ASSIST) using accounting students in the USA and Ireland: a research note", Accounting Education, Vol.13 No.4, pp. 449-459.

Candy, P. (1991), Self-direction for Lifelong Learning, Jossey-Bass Publishers, California.

Caprariis, P., Barman, C., \& Magee, P. (2001). "Monitoring the benefits of active learning exercises in introductory survey courses in science: an attempt to improve the education of prospective public school teachers", The Journal of Scholarship of Teaching and Learning, Vol.1 No.2, pp.1-11.

Catanach, A.H. Jr., Croll, D.B., \& Grinaker, R.L. (2000). "Teaching intermediate financial accounting using a business activity model," Issues In Accounting Education, Vol. 15, No. 4, pp. 583-603.

Chabrak, N., \& Craig, R. (2013). "Student imaginings, cognitive dissonance and critical thinking", Critical Perspectives on Accounting, Vol. 24 No. 2, pp. 91-104.

Cherry, A., \& Reckers, P.M.J. (1985). "A study of the need to change in intermediate accounting courses and textbooks", Issues in Accounting Education, pp. 131-139. 
Choy, S., Bowman, K., Billet, S., Haukka, S., \& Wignall, L. (2008). Effective Models of Employment-based Training, National Centre for Vocational Education Research, Adelaide.

Cope, C., \& Staehr, L. (2005). "Improving Students' Learning Approaches Through Intervention in an Information Systems Learning Environment", Studies in Higher Education, Vol. 30 No.2, pp. 181-97.

Council of Higher Education. (2009). "The state of higher education in South Africa: A report of the CHE advice and monitoring directorate", available at: http://www.che.ac.za/documents/d000201/Higher_Education_Monitor_8.pdf (accessed 07 February 2013).

DeLotell, P.J., Millam, L.A., \& Reinhardt, M.M. (2010). "The Use of Deep Learning Strategies in Online Business Courses to Impact Student Retention", American Journal of Business Education, Vol.3 No.12, pp. 49-56.

Davidson, R.A. (2002). "Relationship of study approach and exam performance", Journal of Accounting Education, Vol.20 No.1, pp. 2944.

Deppe, L., Sonderegger, E., Stice, J., Clark, D., \& Streuling, G. (1991)."Emerging competencies for the practice of accountancy", Journal of Accounting Education, Vol. 9, pp.257-290.

Dewhurst, D.G., Macleod, H.A., \& Norris, T.A.M. (2000). "Independent student learning aided by computers: an acceptable alternative to lectures?" Computers \& Education,Vol.35,pp. 223-241.

Driver, R., \& Easley, J. (1978). "Pupils and paradigms: A review of literature related to concept development in adolescent science students", Studies in Science Education, Vol. 5, pp. 61-84.

Donald, J., \& Jackling, B. (2007). "Approaches to learning accounting: a cross-cultural study", Asian Review of Accounting, Vol. 15 No. 2 , pp. 100-121.

Doran, J., Healy, M., McCutcheon, M., \& O'Callaghan, S. (2011). "Adapting case-based teaching in large class settings: an action research approach", Accounting Education: An International Journal, Vol. 20 No. 3, pp. 245-263.

Dow, K.J., \& Feldman, D.A. (1997). "Current approaches to teaching intermediate accounting," Issues In Accounting Education, Vol. 12, No.1, 61-75.

Dziewulski, A., \& Childs, A. (2012). "A study of the use of independent learning activities with Year 10", available at: http://www.education.ox.ac.uk/wordpress/wp-content/ uploads/ 2012/11/Dziewulski-Anna.pdf . (accessed 15 February 2013).

Eley, M. (1992). "Differential adoption of study approaches within individual students", Higher Education, Vol. 23, pp. 231-254.

Elliott, J. (1991). Action Research for Educational Change, London: Open University Press.

Elliott, R.K. (1997). "Assurance service opportunities: implications for academia", Accounting Horizons, Vol. 11 No. 4, pp.61-74.

Entwistle, N.J. (1987). "A model of the teaching-learning process", in Richardson, J. T. E., Eysenck, M.W., \& Warren Piper, D. (Eds.), Student Learning: Research in Education and Cognitive Psychology. London: S.R.H.E./Open University Press, pp. 13-28.

Entwistle, N.J. (1988). Styles of Learning and Teaching, David Fulton, London.

Entwistle, N.J. (1991). "Approaches to learning and perceptions of the learning environment", Higher Education, Vol. 22, pp. 201-204.

Entwistle, N.J., \& Entwistle, A.C. (1991). Developing, Revising, and Examining Conceptual Understanding: The Student Experience and its Implications (University of Edinburgh: Centre for Research on Learning and Instruction.1991)

Entwistle, N.J., \& Tait, H. (1990). "Approaches to learning, evaluations of teaching, and preferences for contrasting academic environments", Higher Education, Vol. 19, pp. 169-194.

Essential Study Skills (ESS). (2013). "How to organise yourself for independent study (5)", available at: http://www.uk.sagepub.com/burnsandsinfield/BURNS\%20ch\%205.pdf . (accessed 24 January 2013).

Flavell, J. (1963). The developmental psychology of Jean Piaget, Princeton, NJ: Van Nostrand.

Francis, M.C, Mulder, T.C., \& Stark, J.S. (1995). Intentional learning: a process for learning to learn in the accounting curriculum, Accounting Education Change Commission and American Accounting Association, Education Series, No. 12.

Gibbs, G., Morgan, A., \& Taylor, E. (1984). "The world of the learner", In F. Marton, D., Hounsell and N. Entwistle (Eds), The Experience of Learning, Edinburgh: Scottish Academic Press, pp. 165-188.

Gibbs, G. (1995). "Research into student learning" in Research Teaching and Learning in Higher Education, Smith B., and Brown, S (Eds), London: Kogan, pp. 19-29.

Gill G.K., \& Halim N.A. (2007). "The "I" in Independent Learning: The rise in self-managing Learners", available at: http://publications.aare.edu.au/07pap/gil07012.pdf (accessed 03 June 2013)

Gordon, C., \& Debus, R. (2002). "Developing deep learning approaches and personal teaching efficacy within a preservice teacher education context", British Journal of Educational Psychology, Vol. 72, pp. 483-511.

Gow, L., Kember, D., \& Cooper, B. (1994). "The teaching context and approaches to study of accountancy students", Issues in Accounting Education, Vol. 9 No.1,pp. 118-130.

Grayling, I. (2011), "Learning Theories: In Initial Teacher Training, East Midlands Centre for Excellence in Teacher Training", available at: http://www.thelearningchain.net/ Learning\%20Theories\%20in\%20ITT.pdf . (accessed 13 January 2013).

Hall, M., Ramsay, A., \& Raven, J. (2004). "Changing the learning environment to promote deep learning approaches in first-year accounting students", Accounting Education: An International Journal, Vol.13 No.4, pp.489-505.

Harrison, P. (2004). "Unleashing Deep Learning through Questioning", Extract from: Education in a Changing Environment 13th-14th September 2004 Conference Proceedings, available at: www.ece.salford.ac.uk/proceedings/papers/ph_04.rtf (accessed 18 January 2013).

Hinett, K. (2002). "Improving learning through reflection - part one, The Higher Education Academy", available at: http://www.heacademy.ac.uk/assets/documents/resources/ database/id485_improving_learning_part_one.pdf . (accessed 02 
February 2013).

Holec, H. (1981). Autonomy and foreign language learning. Oxford: Pergamon.

Howieson, B. (2003). "Accounting practice in the new millennium: is accounting education ready to meet the challenge?", British Accounting Review, Vol. 35 No. 2, pp. 69-103.

International Federation of Accountants IFAC. (2003), Introduction to International Education Standards, New York: IFAC.

Kolb, D. A. (1976). The Learning Style Inventory: Technical Manual, McBer and Company, Boston.

Laevers, F. (1998). "Understanding the world of objects and of people: Intuition as the core element of deep level learning", International Journal of Educational Research, Vol.29, pp. 69-86.

Laird, T.F.N., Shoup, R., Kuh, G.D., \& Schwarz, M.J. (2008). "The effects of discipline on Deep Approaches to student learning and college outcomes", Research in Higher Education, Vol. 9, pp. 469-494.

Lamb, T. (2004). "Learning independently? Pedagogical and methodological implications of new learning environments", proceedings of the Independent Learning Conference 2003, Published 20 September 2004, available at: http://www.independent learning.org/uploads/ 100836/ila03_lamb.pdf (accessed 23 January 2013).

Lehman, M.W., \& Herring, C.E. (2003). "Creating interactive spreadsheets to provide immediate feedback", Journal of Accounting Education, Vol. 21 No.4, pp. 327-337.

Libby, P.A. (1991). "Barriers to using case studies in accounting classes", Issues in Accounting Education, Vol. 6 No.2, pp. 193-213.

Little, D. (1991). Learner Autonomy. 1: Definitions, Issues and Problems, Authentik, Dublin.

Lucas, U. (2000). "Worlds apart: students' experiences of learning introductory accounting", Critical Perspectives on Accounting, Vol.11 No.4, pp. 479-504.

Lucas, U. (2001). "Deep and Surface Approaches to learning within introductory accounting: a phenomenographic study", Accounting Education: An International Journal, Vol. 10 No.2, pp. 161-184.

Lucas, U., \& Mladenovic, R. (2009). "The identification of variation in students' understandings of disciplinary concepts: the application of the SOLO taxonomy within introductory accounting", Higher Education, Vol. 58 No. 2, pp. 257-83.

Luke, B., \& Hogarth, K. (2011). "Developing and enhancing independent learning skills: Using video tutorials as a means of helping students help themselves", Accounting Research Journal, Vol.24 No.3, pp. 290 - 310.

Mahoney, L.S., \& Dziuban, C. (2000). "Assessing Web-Enhanced Courses and Student Learning Outcomes", Accounting Educators' Journal, Vol. XII, pp. 1-14.

Martin, D.R., \& Wilkerson, J.E. (2006). "An Examination of the Impact of Accounting Internships on Student Attitudes and Perceptions", The Accounting Educators Journal, Vol. XVI, pp. 129-138.

Marton, F. (1981). "Phenomenography—Describing conceptions of the world around us", Instructional Science, Vol. 10, pp. 177-200.

Marton, F., \& Ramsden, P. (1988). "What does it take to improve learning?" in P. Ramsden (Ed.) Improving Learning: New Perspectives, Logan, London, pp.268-286.

Marton, F., \& Säljo, R. (1976). "On qualitative differences in learning. I-Outcome and process", British Journal of Educational Psychology, Vol. 46 No.1, pp. 4-11.

Marriott, P. (2002). "A longitudinal study of undergraduate accounting students' learning style preferences at two UK universities", Accounting Education, Vol.11 No.1, pp. 43-62.

Moore, M.G. (1973). "Towards a theory of independent teaching and learning", The Journal of Higher Education, Vol. 44 No. 9, pp. 66179.

Najoua, L., Annanouch, S., Ihrouchen, A., El Hassan, M., \& Owens, C. (2005). "Perception of Independent Learning", available at: http://aui.ma/old/VPAA/cads/research/cad-research-student-independent-learning.pdf . (accessed 15 January 2013).

Needles, B.E. Jr., \& Powers, M. (1990). "A comparative study of models for accounting education," Issues In Accounting Education, Vol. 5, No. 2, 250-267.

Newman, I., Daniels, M., \& Faulkner, X. (2003). "Open ended group projects a 'Tool' for more effective teaching" in Proceedings of Australasian Computer Education Conference (ACE2003), Australia, 2003, pp.95-103

Palfreyman, D., \& Baba, H. (2010). "Changing perceptions of independent learning: a conversation, Independence 51", available at: http://www. learnerautonomy.org/51David Heather.pdf . (accessed 13 January 2013).

Pascarella, E.T., Wang, J., Laird, T.F.N., \& Ribera, A.K. (2012). "Impacts of Clear and Organized Classroom Instruction and Deep Approaches to Learning on Four-Year Growth in Critical Thinking Skills and Need for Cognition", available at: http://www.education. uiowa.edu/centers/docs/cdre-documents/pascarella-et-al-impacts-of-organized-instruction. pdf?sfvrsn=0 . (accessed 13 January 2013).

Pask, G. (1988). "Learning Strategies, Teaching Strategies, and Conceptual or Learning Style", in Schmeck R. (Ed), Learning Strategies and Learning Styles: Perspectives on Individual Differences. New York, NY: Plenum, pp. 83-100.

Percy, K.A., \& Salter, F.W. (1976). "Student and staff perceptions and 'the pursuit of excellence' in British higher education", Higher Education, Vol. 5 No. 4, pp. 457-73.

Peters, R. (1964). Education as initiation: An inaugural lecture delivered at the University of London Institute of Education. London University Institute of Education Studies in Education, England.

QAAHE. (2000). Subject Benchmark Standard for Accounting. Quality assurance Agency for Higher Education, Gloucester.

Race, P. (2005). 500 Tips for Open and Online Learning, $2^{\text {nd }}$ ed., Routledge Falmer, London.

Ramsden, P. (1992). Learning to Teach in Higher Education, Routledge, London.

Read, A., \& Hurford, D. (2008). "Opportunities for personalised learning: enabling or overwhelming?" University of Cumbria, Vol 2 
No.1,pp. 43-50

Rebele, J.E., Apostolou, B.A., Buckless, F.A., Hassell, J.M., Paquette, L.R., \& Stout, D.E. (1998). "Accounting education literature review (1991-1997), Part I: curriculum and instructional approaches", Journal of Accounting Education, Vol.16 No.1, pp. 1-51.

Rossiter, J.A. (2010). "Student engagement with MATLAB and supporting independent learning, Department of Automatic Control and Systems Engineering, University of Sheffield", available at: www.heacademy.ac.uk/assets/.../4_april MATLAB_Rossiter.ppt . (accessed 02 February 2013).

Rorty, R. (1967). "Intuition," in Edwards, P (Ed.), The Encyclopedia of Philosophy, Macmillan Reference, New York, pp. $204-212$.

Rubena, S. (2003). "Helping students become autonomous learners: Can technology help?" Available at: http://www.tewtjournal.org/VOL\%206/ISSUE\%203/03_HELPING STUDENTS.pdf (accessed 13 September 2013).

Russel International Excellence Group RIEG. (2010). "Research-led learning: the heart of a

Russell Group university experience", available at: http://www.russellgroup.ac.uk/ uploads/Learning-in-a-research-intensive-environment. pdf . (accessed 02 February 2013).

SAICA. (2010). SAICA Competency Framework: Detailed Guidance for Academic Programmes, South Africa Institute of Chartered Accountants, Johannesburg.

Samkin, G., \& Francis, G. (2008). "Introducing a Learning Portfolio in an Undergraduate Financial Accounting Course", Accounting Education: An International Journal, Vol.17 No.3, pp. 233-271.

Sanchez, L.A., Hight, T. K., \& Gainen, J. (1995). "Critical thinking and design: evolution of a freshman engineering graphics course", New Directions for Teaching and Learning, Vol.1995 No. 61, pp. 67-76.

Schmutte, J. (1986). "Accounting Internships: The State of the Art", Journal of Accounting Education, Vol. 4 No.1, pp. 227-236.

Sharma, D.S. (1997). "Accounting students' learning conceptions, approaches to learning, and the influence of the learning-teaching context on approaches to learning", Accounting Education: an international journal, Vol. 6 No.2, pp. 125-146.

Shuell, T.J. (1986). "Cognitive conceptions of learning", Review of Educational Research, Vol.56 No.4, pp. 411-436.

Smith, A., \& Turner, J. (2012). "Problem Solving and Independent Learning: Principles \& Practices", available at: http://www.alistairsmithlearning.com/wp-content/uploads/ 2012/ 09/Problem-Solving-and-Independent-Learning.pdf . (accessed 20 January 2013).

Stoner, G., \& Milner, M. (2010). "Embedding generic employability skills in an accounting degree: development and impediments", Accounting Education: An International Journal, Vol. 19 Nos 1-2, pp. 123-138.

Strickland, R. (1985). "Scholarship in the academic circus or the balancing act at the minority side show", University of San Francisco Law Review, Vol. 20, pp. 491-502.

Sundem, G.L., \& Williams, D.Z. (1992). "Changes in Accounting Education: Preparing for the twenty-first Century", Accounting Education, Vol.1 No.1, pp. 55-61.

Svensson, L. (1977). "On qualitative differences in learning. III: Study skill and learning", British Journal of Educational Psychology, Vol.47 No.3, pp. 233-243.

The Big Eight. (1989). Perspectives on Education: Capabilities for Success in the Accounting Profession, Arthur Andersen \& Co, Arthur Young, Coopers \& Lybrand, Deloitte Haskings \& Sells, Ernst \& Whinney, Peat Marwick Main \& Co, Price Waterhouse, Touche Ross.

Trigwell, K., \& Prosser, M. (1991). "Improving the quality of student learning: the influence of learning context and student approaches to learning on learning outcomes", Higher Education, Vol. 22 No.3, pp. 251-266.

Turner, J.L., Holmes, S.A., \& Wiggins, C.E. (1997). "Factors associated with grades in intermediate accounting," Journal of Accounting Education, Vol. 15, No. 2, pp. 269-288.

Verduin, J.R., \& Clark. T.A. (1991). Distance Education: The Foundations of Effective Practice, Jossey-Bass, San Francisco, USA.

Waks, L.G. (2006). "Intuition in Education: Teaching and Learning without thinking", available at: http://www.philosophy-ofeducation.org/pdfs/Friday/Waks.pdf (accessed 14 September 2013).

White, F. (2008). The Daily Writer: 365 Meditations To Cultivate A Productive And Meaningful Writing Life, Writer's Digest Books, U.S.A

Zapalska, A.M., \& Dabb, H. (2002). "Learning styles", Journal of Teaching in International Business, Vol. 13 Nos 3/4, pp. 77-97.

Zeegers, P. (2001). "Approaches to learning in science: a longitudinal study", British Journal of Educational Psychology, Vol.71 No.1, pp. $115-132$.

Zhang, L., \& Sternberg, R.J. (2000). "Are learning approaches and thinking styles related? A study in two Chinese populations", The Journal of Psychology, Vol. 134 No. 5, pp. 469-489

Zhang, D., Zhao, J., Zhou, L., \& Nunamaker, J. (2004). "Can e-learning replace classroom learning?" Communications of the ACM, Vol. 47 No. 5 , pp. $75-79$. 


\section{Appendix 1}

Examining the relationship between Independent research and Deep Learning among BAccSci and BComAcc final year students

Table A1: Examining the relationship between Independent research and Deep learning among BAccSci and BComAcc final year students

\begin{tabular}{|l|c|c|c|}
\hline \multicolumn{1}{|c|}{ Variable } & \multicolumn{2}{c|}{ Outcome in numbers } & \\
\hline & Yes & No & Total \\
\hline Independent research & 152 & 10 & 162 \\
\hline Deep learning & 135 & 27 & 162 \\
\hline Total & 287 & 37 & 342 \\
\hline
\end{tabular}

Table A2: Showing Chi-squared computations

\begin{tabular}{|c|c|c|c|c|}
\hline Variable & Fo & Fe & $(\mathrm{Fo}-\mathrm{Fe})^{\mathbf{2}}$ & $(\mathrm{Fo}-\mathrm{Fe})^{2} / \mathrm{Fe}$ \\
\hline Independent Learning & & & & \\
\hline Yes & 152 & 143.5 & 72.25 & 0.503484 \\
\hline No & 10 & 18.5 & 72.25 & 3.9054 \\
\hline Deep Learning & & & & \\
\hline Yes & 135 & 143.5 & 72.25 & 0.503484 \\
\hline No & 27 & 18.5 & 72.25 & 3.9054 \\
\hline & & & $\mathbf{X}^{2}$ Stat & 8.817768 \\
\hline
\end{tabular}

\section{Appendix 2}

Examining the relationship between independent research and improved understanding of accounting concepts on BAccSci and BComAcc final year students

Table A3:Examining the relationship between independent research and improved understanding of accounting concepts among BAccSci and BComAcc final year students

\begin{tabular}{|l|c|c|c|}
\hline \multicolumn{1}{|c|}{ Variable } & \multicolumn{2}{c|}{ Outcome in numbers } & \\
\hline & Yes & No & Total \\
\hline Independent research & 152 & 10 & 162 \\
\hline Improved understanding of concepts & 98 & 64 & 162 \\
\hline Total & 250 & 74 & 324 \\
\hline
\end{tabular}

Table A4: Showing Chi-square computations.

\begin{tabular}{|c|c|c|c|c|}
\hline Variable & $\mathrm{Fo}$ & $\mathrm{Fe}$ & $(\mathrm{Fo}-\mathrm{Fe})^{2}$ & $(\mathrm{Fo}-\mathrm{Fe})^{2} / \mathrm{Fe}$ \\
\hline Independent Learning & & & & \\
\hline Yes & 152 & 125 & 729 & 5.832 \\
\hline No & 10 & 37 & 729 & 19.7027 \\
\hline Improved understanding of concepts & & & & \\
\hline Yes & 98 & 125 & 729 & 5.832 \\
\hline No & 64 & 37 & 729 & 19.7027 \\
\hline & & & $\mathbf{X}^{2}$ Stat & 51.0694 \\
\hline
\end{tabular}


